\title{
THE USE OF NST TOEFL EXPLORER TO IMPROVE THE STUDENTS' MASTERY IN GRAMMAR TOEFL
}

\author{
Barotun Mabaroh ${ }^{1}$ \\ Ninik Suryatiningsih ${ }^{2}$ \\ English Education Study Program, STKIP PGRI Pasuruan \\ barotunmabaroh@yahoo.com
}

\begin{abstract}
Optimizing information and communication technology (ICT) in language learning is best solution for boring conventional classes. It promises both lecturers and students better achievement in teaching and learning. Especially in Grammar for TOEFL (name of course taught in the fourth semester of English Education Study Program at STKPI PGRI Pasuruan), did the (lecturer) researcher decide to use NST TOEFL Explorer as one of ICT products to solve some instructional problems. In order to achieve the objective, thus this research was designed as a classroom action research and it used field notes, interview, and TOEFL test as instruments. The use of NST TOEFL Explorer did not simply require students to operate the application; therefore the research team seeked for and implemented working strategies to improve the students' mastery in Grammar for TOEFL. The data from fieldnotes discovered the students were feeling enjoyable in using NST TOEFL Explorer. Moreover, from intervew, the students stated that learning grammar by NST TOEFL Explorer could make them motivated and confident in joining real TOEFL. The data collected by TOEFL test showed that the students could gain high scores. As a result, NST TOEFL Explorer could improve the students' mastery in Grammar for TOEFL not only cognitively but also psychomotorically.
\end{abstract}

Keywords: Grammar TOEFL, NST TOEFL Explorer, Working Strategies

\section{INTRODUCTION}

Grammar is a bunch of rules on using language structures both in oral and written form (Rohmah, 2009). Understanding rules on grammar is very important because it may be claimed as a starting point of learning English as a foreign language in Indonesia. Grammar shows how utterances in English can be expressed appropriately; because it is not only about transferring ideas to receivers through English but also it forms consistency hence English can be understandable (Purpura, 2011).

In formal education, prominently at university level, grammar can be taught using various ways. Imananda (2011 as stated in Cahyono and Widiati, 2011) suggests that grammar should be taught practically and enjoyably using information and communication technology (ICT). In order to make teaching and learning grammar enjoyable, Asizah (as stated in Cahyani and Cahyono, 2011) says grammar should be better taught through interractive games. Furthermore, Nugroho (as stated in Cahyono

British, Jurnal Bahasa dan Sastra Inggris 
and Indah, 2012) views lecturers may teach grammar using text analysis in order to make them conscientious.

Considering the experts' suggestion mentioned, the (lecturer) researcher thought it is urgent to optimize ICT product in teaching and learning grammar. It was because the use of ICT product supports better achievement in learning English effectively and efficiently (Faridi as stated in Cahyono, 2010). According to Fachrurrazy (2012), better achievement here refers to mastering English skills; speaking, writing, listening, and reading, and its elements; grammar, vocabulary, and pronunciation. In short, optimizing ICT product can improve the students' mastery especially in grammar.

ICT products generally make students very individualistic (Sutarman, 2012). So, it is important to integrate using ICT and interractive games. But, teaching and learning grammar should still focus on provoking students conscientious in understanding and analyzing text grammatically. Therefore, the (lecturer) researcher with collaborators was sure to still lead students to analyze texts grammatically.

In designing strategies which integrate the use of ICT, games, and grammatical analysis, the (lecturer) researcher with collaborators looked into instructional problems in Grammar for TOEFL course. This was the key for the (lecturer) researcher and collaborators in order to formulate working strategies which can improve the students' mastery. And based on the preliminary study, it was found that teaching and learning Grammar for TOEFL course had done without optimizing ICT. The (lecturer) researcher taught using auditory style, interview, and games. Yet, it is important to make students aware of using ICT in any aspect especially for their academic achievement. The other instructional problem was the students' less concentration. It was found that the (lecturer) researcher had already implemented teaching grammar using games but the students seemed more focused on enjoying the grammar game than on understanding parts of grammar well. As a result, most students could not achieve good score in structure/ grammar section of TOEFL (see appendix 1).

Based on the findings mentioned, the (lecturer) researcher and collaborators decided to use NST TOEFL Explorer. The decision of using NST TOEFL Explorer was because it provides some advantages than other applications which are purposively aimed for solving the instructional problems (Rakha, 2012). First, NST TOEFL Explorer provides tutorial feature. This feature overcame the students' problem in 
simplifying too complex materials in grammar for TOEFL; thus they could remember almost all grammatical rules easily. Second, practice feature on NST TOEFL Explorer encouraged the students' conscientiousness because it allows the students to exercise themselves in dealing with TOEFL test items on grammar and get feedbacks for their correct/ incorrect answers systematically. Third, examination feature could make the students confident to conduct the real TOEFL since it stimulated them to answer standardized-TOEFL test items on grammar in 25 minutes. After doing the examination, the system of NST TOEFL Explorer shows the gained score such as 370, 430, 560, etc. Moreover, review feature in NST TOEFL Explorer could give the students reflection or reason of why they clicked incorrect answers in the examination. Last, progression feature could record the students' improvement by displaying all gained scores from the first examination until the last. This feature motivated them to achieve better in further examination.

The use of NST TOEFL Explorer did not simply require students to operate, but the (lecturer) researcher with collaborators designed and implemented working strategies to improve the students' mastery in Grammar for TOEFL. Thus, the objective of the present research was to discover working strategies on the use of NST TOEFL Explorer which can improve the stduents' mastery in grammar for TOEFL. As a result, NST TOEFL Explorer could improve the students' mastery in Grammar for TOEFL not only cognitively but also psychomotorically.

\section{RESEARCH METHOD}

This research was classroom action research. A classroom action research aims at developing a certain instructional strategy to solve practical instructional problems in English classrooms (Latief, 2011: 143). Besides, the strategy should contribute to the improvement of English teaching-learning practices.

This research started with observing and identifying problems (preliminary study). As it mentioned in the intrduction, the problems occured in Grammar for TOEFL class were the students' less contentration and urgency of using ICT. Then, this research proceeded into planning, acting, observing, and reflecting stage. According to Latief (2011:145), a Classroom Action Research (CAR) is carried out in several cycles. Only if the objective of the research achieved the criteria of success, had the research no longer required the implementation of the next cycle.

\section{British, Jurnal Bahasa dan Sastra Inggris}


This research was carried out based on instructional problems faced by the fourth semester students in Grammar TOEFL course at English Education Study Program, STKIP PGRI Pasuruan. Indeed, the students could not achieve good score in dealing with section two (structure/grammar) questions of TOEFL. There are 40 questions in section two of TOEFL, but only a few of the students could give above 20 correct answers. This means most students tended to give wrong answers on section two questions of TOEFL.

Based on the discussion with the research team, the research team agreed to use NST TOEFL Explorer which has previously been recommended by many users in some English private courses. As mentioned in the introduction, NST TOEFL Explorer was chosen because of its advantages including the tutorial menu and try out of TOEFL test. In relevance with the objective of a classroom action research, the research team had discussed working strategies on using the application which hence could improve the students' mastery in grammar for TOEFL. Besides, the research team determined the criteria of success both form the product and the process aspect.

Due to this research only focused on the implementation of strategy in using NST TOEFL Explorer which can improve grammar mastery, hence based on the applicable TOEFL conversion rate, 500 score (the standard score) will be obtained if a student is able generate 29 correct answers on grammar session of TOEFL try-out test (Rogers, 2011). Therefore, 29 correct answers to $70 \%$ of the number of students was one of the criteria of success in this research. The rest $30 \%$ of the number of students should be able to obtain at least 22 correct answers on the grammar session.

Secondly, this research succeeded if at least $70 \%$ of students stated possitive attitude (clicking on YES with supporting reason) and maximum $30 \%$ of students stated negative attitude (clicking on NO with supporting reason) toward the use of TOEFL Explorer NST application . Possitive and negative attitude is inferred from the result of questionnaire which was distributed to students in the end of each cycle (see appendix 2). The students' response on questionnaire was calculated using the following formula

$$
\mathrm{RQ}-\ldots=\frac{\mathrm{ans} * 100}{\mathrm{n}}
$$

Notes:

Response of question number- $\quad=$ RQ-...

\section{British, Jurnal Bahasa dan Sastra Inggris}




$$
=\text { ans }
$$

Total of answers

$$
=\mathrm{n}
$$

From the calculation using the formula above, then the research team will get a percentage of the student response. For example, question no 1 has the total of answers 30, with 27 positive "YES" response and 3 negative "NO" response, so this data can be calculated as follows

a. Positive (Yes) response

$$
\mathrm{RQ}-1=\underline{27 * 100}=90
$$

b. Negative (No) response

$$
\text { RQ-1 }=\underline{3 * 100}=10
$$

30

Based on the above calculation example, it can be concluded $90 \%$ of the number of students responded positively and only $10 \%$ responded negatively to question 1 in the questionnaire.

In addition, the research team also collected supporting data in the form of photographs of research implementation. The research team also captured process data using field-notes instrument that served to provide important descriptions of the strength and the weaknesses of the implementation (see appendix 3). The researcher also employed interview and designed the interview guide as in appendix 4.

\section{RESEARCH FINDING AND DISCUSSION}

This part displays findings of the research and the critical analysis toward it. The findings covers the working strategies in using NST TOEFL Explorer. And, the critical analysis explains how well the strategies could improve the students' mastery in grammar for TOEFL.

\section{Findings}

This research was successfully done in two cycle. In cycle one, the students could not achive the criteria of succes in terms of the TOEFL score on structure/ grammar section. Thus, it then continued to cycle two. In cycle two, the students 
obtained better score and met the criteria of success. So, the (lecturer) researcher with collaborators stopped the action of the research.

The success of the research in cycle two was due to the revised strategies (from cycle 1). In cycle 1, the action of teaching grammar using the TOEFL Explorer NST was held in three meetings. The first meeting was done on Thursday, 15 March 2019. The second meeting was done on Thursday, 22 March 2019. And, the third meeting was done on Thursday, 05 April 2019. Each meeting was allocated 100 minutes in accordance with academic rules in STKIP PGRI Pasuruan, at 09.20-11.00 (Class A) and 11.00-12.40 (Class B).

In the first five minutes, teaching grammar using NST TOEFL Explorer started with checking student attendance and giving short recognition to NST TOEFL Explorer. After that, the students followed the tutorial session in NST TOEFL Explorer for 30 minutes. During the tutorial, the students were not allowed to write or record anything and they just needed to concentrate with the tutorial contents shown by LCD.

In the next 25 minutes, the students started working on grammar questions in NST TOEFL Explorer; shown by LCD projector from the researcher's laptop thus the students had to deal with the same package of grammar question. This session functioned only as an exercise. After that, the students had been instructed to exchange their answer sheets with mates. The researcher started discussion on the correct answers. The students were allowed to participate by giving their opinion. They should state their answers and logical reasons. This discussion was actually set in 25 minutes, but it spent more time or until 35 minutes. In this wasting time, the discussion covered only 25 items (in meeting 1) and 32 (in meeting 2) from 40 test items. Moreover, some students dominated the discussion while the others were just sitting and listening to.

In the next five minutes, the researcher concluded the result of teaching-learning process and then closed the class. In brief, the strategies impplemented in cycle can be seen as the following table

Table 1 . The teaching-learning scenarion in cycle 1

\begin{tabular}{ccc}
\hline No & Activities & Time Allotment \\
\hline $\mathbf{1}$ & Opening and checking attendance & 5 minutes \\
\hline
\end{tabular}




\begin{tabular}{clc}
\hline $\mathbf{2}$ & Tutorial & 30 minutes \\
\hline $\mathbf{3}$ & Working on the exercise & 25 minutes \\
\hline $\mathbf{4}$ & Discussion on the exercise & 35 minutes \\
\hline $\mathbf{5}$ & Conclusion and closing & 5 minutes \\
\hline
\end{tabular}

The strategies explained above were done in the firts and the second meeting of cycle 1 . But in the third meeting, the students were required to deal with grammar question of TOEFL accessed by their own laptop. This session was called as TOEFL Try-out test. Considering every operation of NST TOEFL Explorer would always bring up different test package, thus the researcher believed that they would not be able to cheat to their mates. In this meeting, the collaborators helped the researcher in controlling the process of test. The students were given 15 minutes to prepare their laptops and other technical supports. Next, the researcher open the session, checked the attendance, and red the rules of the test in 10 minutes. The students were given 25 minutes to deal with 40 grammar questions in NST TOEFL Explorer. After that, the researcher and collaborators listed the students' score of TOEFL try-out test shown automatically by NST TOEFL Explorer system. This spent 10 minutes. Furhermore, the students were required to fill in the questionnaire in 10 minutes. Next, the researcher closed the session and chose some students to be interviewed, hence allowed the others to leave the class.

The result in cycle 1 revealed that 16 students (64\%) in class A achieved the criteria of TOEFL try-out test core, but 9 students (36\%) failed. In class B, 17 students $(68 \%)$ met the criteria yet 8 students (32\%) failed (see appendix 5). The result of questionnaire showed that $89,3 \%$ of students in class A had positive attitude toward the implementation, but $10,67 \%$ felt negative attitude. $86,67 \%$ of students in class B had positive attitude toward the implementation, but $13,33 \%$ felt negative attitude. Comparing this result with the criteria of success, so it can be concluded that this research needed to continue the implementation to cycle two certainly with revised strategies.

In cycle 2, the first meeting was done on Thursday, 12 April 2019. The second meeting was on Thursday, 19 April 2019. And, the third meeting was on 26 April 2019. 
Each meeting was allocated 100 minutes in accordance with academic rules in STKIP PGRI Pasuruan, at 09.20-11.00 (Class A) and 11.00-12.40 (Class B). In this cycle, the researcher with collaborators had revised the strategies on the use of NST TOEFL Explorer to improve the students' grammar mastery. The revised strategies used for cycle 2 can be seen as follows.

Table 2. The teaching-learning scenarion in cycle 2

\begin{tabular}{clc}
\hline No & \multicolumn{1}{c}{ Activities } & Time Allotment \\
\hline $\mathbf{1}$ & Opening and checking attendance & 5 minutes \\
\hline $\mathbf{2}$ & Grouping & 5 minutes \\
\hline $\mathbf{3}$ & $\begin{array}{l}\text { Working on the exercise and the } \\
\text { discussion }\end{array}$ & 80 minutes \\
\hline $\mathbf{4}$ & Reflection and motivation & 5 \\
\hline $\mathbf{5}$ & Tasking and closing & 5 \\
\hline
\end{tabular}

In the first and the second meeting of cycle two, the researcher with the collaborators open the session and checked the students' attendance in 5 minutes. After that, the researcher continued to tutorial session. In different with cycle 1 , the students must join in groups determined by the researcher. Each group consisted of 4-5 students. The researcher also pointed out the captain of the group who was responsible for leading members to participate in the discussion. This process required 5 minutes to manage members and also sitting position.

Next, the researcher continued with working on the exercise and the discussion. In cycle 1, the students were required to work on the exercise individually and then join in class discussion led by the researcher. But, in cycle 2, the students in groups must concentrate well because the researcher only gave limited time to think of the answer of grammar question displayed and directly asked the representative of each group to answer and give logical reason.

Once the researcher showed a question on NST TOEFL Explorer, did she count 40 seconds using stopwatch and ask the representatives to state the answers and reasons. 
The fastest captain who raised hand, the group was approved to take the chance to get points of answering. Yet, the researcher also set rules that only the captain could raise hand but the members were required to participate by turns or would be vain (got no point). In conditioning this rule, the researcher was helped by the two collaborators.

The class both A and B seemed very enthusiastic and alive. No one dominated the session and the students felt confident because they had discussed the answer and reason with members of groups. This session run very well. The researcher planned the students could answer and discuss 40 grammar question on the application. Fortunately, because of the students' enthusiasm, the researcher could display until 50-55 items (opening next test-package). And this was a pride for them.

In reflection and motivation session, the researcher invited the students to express their impression and expectation toward the use of NST TOEFL Explorer to improve grammar mastery. Next, the researcher gave the students a task of making grammar notes of the most difficult part to understand. The researcher assessed the notes at home and gave points for it. The note should be written down in BUKU SAKU.

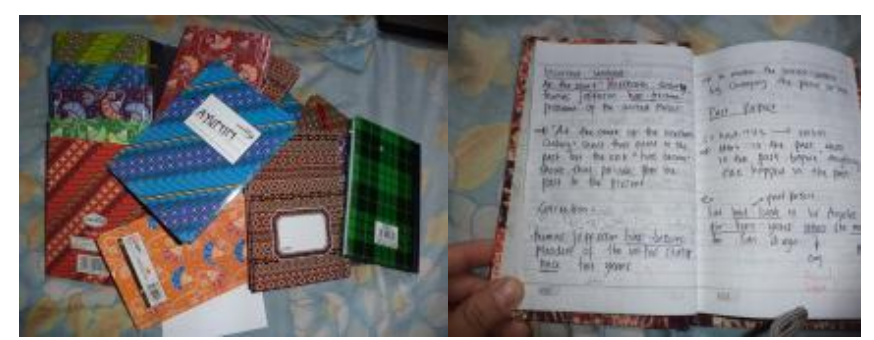

Figure 1. BUKU SAKU \& the students' grammar notes

In the third meeting, the students were required to deal with grammar question of TOEFL accessed by their own laptop as done in cycle 1 . The run-down and the rules of TOEFL try-out test in this cycle were as in cycle 1 too. First, the students were given 15 minutes to prepare their laptops and other technical supports. Next, the researcher open the session, checked the attendance, and red the rules of the test in 10 minutes. The students were given 25 minutes to deal with 40 grammar questions in NST TOEFL Explorer. After that, the researcher and collaborators listed the students' score of TOEFL try-out test in 10 minutes. Next, the students filled in the questionnaire in 10 minutes. Last, the researcher closed the session and chose some students to be interviewed and allowed the others to leave the class. 
The implementation of strategies in cycle 2 resulted better and could achieve the criteria of success. In details, as the criteria of success required, 18 students (72\%) in class A achieved the criteria of TOEFL try-out test core, and only 7 students $(28 \%)$ failed. Furthermore, 19 students (76\%) succeeded and 6 students (24\%) failed in class B (see appendix 6). Although the failed students could not make 29 correct answers, they could give at least 22 correct answers. The average of correct answers was 31 for class A and 33 for class B. This meant that the students' mastery in grammar for TOEFL was above the criteria of success (29). This indicates that the strategies on the use of NST TOEFL Explorer worked successfully to improve the students' mastery in grammar for TOEFL.

88, 67\% positive attitude in class A was gained in cycle 2. $11,33 \%$ was calculated as negative attitude from class A. Students in class B had positive attitude with $84 \%$ and negative attitude with $16 \%$ toward the implementation. In comparison with the result in cycle 1, the present result decreased but it could still meet the criteria of success (70\% positive attitude and $30 \%$ negative attitude). Reflecting the result of both TOEFL try-out test and the questionnaire, the researcher and the collaborators concluded that this research succeeded in improving the students' mastery in grammar TOEFL.

\section{Discussion}

In this discussion, the researcher would review strategies used in cycle 1 and strategies used in cycle 2 . In cycle 2 , there was no session of giving tutorial but the students could achieve better in TOEFL try-out test in cycle 2 . Reminding that Grammar for TOEFL (4) course was the course which was preceeded with Intensive Grammar (1), Sentence Grammar (2), and Intermediate Grammar (3), so it can be said that the students might have discussed and understood almost all grammar materials at the previous courses. Indeed, they needed only a review of grammar than tutorial which might make them bored.

According to Duverger (2016), boredom has been linked to a very diverse range of possible psychological, educational, and social problems. In this case, the students felt boredom thus they could not achieve the targeted score in cycle 1 . But, in cycle 2, the researcher changed the strategies into learning by cooperate with others (grouping) and tasking of making notes on difficult grammar materials. This strategy means the 
researcher allowed the students to construct their own need by assessing their own position within groups. They got motivated by sharing with friends.

In cycle 1, the implementation pushed the students to participate by themselves, but in cycle 2 they joined in groups which gave them emotional and cognitive support. Grouping gave them emotional support means they could get more confident to participate because their members also contributed. According to Harmer (2007), in a group working, every student could use the best of their skills to make sure of quality. In short, grouping ensures one's belief and understanding in grammar thus they could feel more confident in cycle 2. Cognitive support in grouping could not be denied because every member in group can learn new or 'forgotten' grammar materials from the others. They got the option to learn from each other.

Experts proposed disadvantages of grouping including wasting time(Harmer, 2007). To work in group is very strenuous and also takes up a lot of time. But, in cycle 2 of the present research, grouping could make the students more focused and moreover they could finish discussion more than one test package. So, the present research result proved that grouping does not always waste time when the lecturer/ instructor/ fasilitator could manage the time well and provide consequence of timing.

The strategy on using NST TOEFL Explorer also arised competitiveness because the (lecturer) researcher would admit the fastest representative who responded. This did not only promote competitiveness but also keep the students focused and train them to take action critically in flash.

Providing self-reflection and giving motivation could make the students realized about their personal need. It was effective to encourage them contribute in groups. Last, tasking could keep the students studying at home. This actually showed their intention and attention to themselves beside fulfilling the (lecturer) researcher's requirement.

\section{CONCLUSION AND SUGGESTION}

In this section, the researcher gives conclusion that a classoom action research is not merely about using good instructional media but also discovering strategies to solve instructional problems in classes. Therefore, the present research discussed the working strategies on the use of NST TOEFL Explorer which can improve the students' mastery in grammar for TOEFL. This research resulted the working strategies on the use of NST TOEFL Explorer were 1) integrating ICT with grouping technique, 2) Avoiding the 
students' boredom because of repeating explanation of material, 3) arising competitiveness, 4) asking the students to reflect themselves and get motivation, and 5) keeping the students learning outside the class. By the five strategies, the students could get better score in TOEFL try-out test and get more confident to real TOEFL test.

\section{REFERENCES}

Rohmah, Z. (2009). TEFLIN Journal. EFL Materials in Madrasah Tsanawiyah: What Do They Really Need?, Volume 20 Number 1 Februari 2009.

Purpura, J..E. (2011). Assessing Grammar. Cambridge University Press.

Cahyono, BY., \& Widiati, U. (2011). The Teaching of English as a Foreign Language in Indonesia. Malang: UM Press.

Cahyono, BY., \& Indah, RN. (2012). Second Language Research and Pedagogy. Malang: UM Press.

Cahyono, BY. (2010). Teaching English by Using Internet Resources. Malang: UM Press.

Sutarman. (2012). “Buku Pengantar Teknologi Informasi”. Jakarta: Bumi Aksara.

Fachrurrazy. (2012). Teaching English as a foreign language for teachers in Indonesia. Malang: State University of Malang Press.

http://rakhamgn.blogspot.com/2012/11/nst-toefl-explorer-latihan-listening-un.html diakses tanggal 12 Juni 2019.

Rogers, B. (2011). The Complete Guide to the TOEFL Test; PBT Edition. Boston: Heinie Cengage Learning.

Latief, M.A. (2011). Research Methods on Language Learning (An Introduction). Malang: UM Press.

Duverger, P. (2016). Boredom? What boredom?! Enfances et Psy, 70(2), 55-62. https://doi.org/10.3917/ep.070.0055

Harmer. (2007). The Practice of English Language Teaching, the Fourth edition. Longman Pearson Education Limited. 